\title{
Chronic intermittent haemofiltration and haemodialysis in end stage chronic heart failure with oedema refractory to high dose frusemide
}

\author{
Tom P J Dormans, Rien M C Huige, Paul G G Gerlag
}

\begin{abstract}
Objective-To assess the benefits and problems of chronic intermittent treatment with haemofiltration or haemodialysis or both in patients with severe chronic heart failure (New York Heart Association class III or IV) and oedema refractory to pharmacological treatment. Design and setting-A retrospective casecohort study. A general hospital in The Netherlands.

Patients-The results of chronic intermittent treatment with haemofiltration $(n=$ 10) or haemodialysis $(n=2)$ were analysed in patients with severe chronic heart failure, predominantly due to coronary heart disease, and oedema refractory to a pharmacological regimen including high dose frusemide.
\end{abstract}

Intervention-Patients had an average of 25 (SD 38) treatments.

Results-There was improvement of NYHA class IV to III in seven patients. However, this was not reflected in a decrease in hospital admission: only two patients could be managed as outpatients. The median survival after start of the treatment was 24 days (varying from 0 to 393 days). In four patients the treatment was discontinued after discussion with the patient and family.

Conclusions-The use of chronic intermittent haemofiltration and haemodialysis is of limited value in end stage chronic heart failure with oedema, refractory to maximal conventional treatment.

(Heart 1996;75:349-351)

Keywords: haemofiltration; end stage heart failure; high dose frusemide.

\begin{tabular}{|c|c|c|c|c|c|c|}
\hline Patient & $\operatorname{Sex}$ & $\begin{array}{l}\text { Age } \\
\text { (years) }\end{array}$ & NYHA & $\begin{array}{l}\text { Underlying } \\
\text { disease }\end{array}$ & $\begin{array}{l}\text { Frusemide } \\
\text { dosage (mg) }\end{array}$ & $\begin{array}{l}\text { Other } \\
\text { medication }\end{array}$ \\
\hline 1 & $\mathbf{M}$ & 64 & IV & CHD & $500 \mathrm{Po}$ & Dig, Vd \\
\hline 2 & $\mathrm{~F}$ & 75 & IV & CHD & $1000 \mathrm{Po}$ & Dig \\
\hline 3 & $\mathbf{M}$ & 62 & IV & $\mathrm{CM}$ & $1500 \mathrm{Po}$ & Dig, Ace \\
\hline 4 & $\mathbf{M}$ & 77 & IV & CHD & $1000 \mathrm{Po}$ & Dig, Ace, Vd, Do \\
\hline 5 & $\mathbf{M}$ & 71 & IV & $\mathrm{CHD}$ & $2000 \mathrm{IV}$ & Dig, Ace \\
\hline 6 & M & 76 & IV & CHD & $1500 \mathrm{Po}$ & Dig, Ace, Vd \\
\hline 7 & M & 61 & III & CHD & $2000 \mathrm{IV}$ & Dig, Ace \\
\hline 8 & $\mathrm{~F}$ & 71 & IV & VAD & $2000 \mathrm{Po}$ & Dig, Ace, Do \\
\hline 9 & $\mathbf{M}$ & 56 & IV & CHD & $1000 \mathrm{Po}$ & Ace \\
\hline 10 & M & 72 & IV & CHD & $2000 \mathrm{Po}$ & Ace, Do \\
\hline 11 & $\mathbf{M}$ & 66 & IV & $\mathrm{CHD}$ & $4000 \mathrm{IV}$ & Ace, Do \\
\hline 12 & $\mathbf{M}$ & 64 & IV & CHD & $3000 \mathrm{IV}$ & Dig, Ace, Do \\
\hline
\end{tabular}

Ace, angiotensin converting enzyme inhibitors; CHD, coronary heart disease; CM, cardiomyopathy; Dig, digitalis; Do, dopamin; F, female; IV, intravenously; $\mathrm{M}$, male; Po, orally; VAD, valvar disease; Vd, vasodilator.
Chronic heart failure is a major health problem. ${ }^{1}$ Ultimately many patients become unresponsive to maximal conventional treatment and remain severely symptomatic. Short term relief of symptoms may be obtained by removing fluid, either by venesection, haemodialysis, haemofiltration, or peritoneal dialysis. ${ }^{2-7}$ The use of these techniques in the acute setting may be worthwhile and can result in the restoration of diuretic responsiveness.

Chronic intermittent haemofiltration and continuous ambulatory peritoneal dialysis of patients with heart failure may improve survival. ${ }^{8-11}$ The wide range in outcome in these studies reflects the differing definitions of maximal pharmacological treatment and the heterogeneity of the patients studied. Often data are lacking about the maximum doses of diuretics, the use of inotropic or preload reducing drugs, and the severity of left ventricular dysfunction at the start of chronic intermittent treatment. We therefore set out to determine whether haemofiltration and haemodialysis used in this way can improve the quality of life in patients with chronic heart failure unresponsive to maximum conventional treatment, including high doses of frusemide (500 to $4000 \mathrm{mg}$ daily dosage).

\section{Methods}

PATIENT CHARACTERISTICS

In this retrospective study we reviewed data of 12 patients who were treated in our hospital between October 1979 and April 1991. The clinical characteristics of the studied patients are shown in table 1 . The mean age of the patients was 68 years, the predominant cause of chronic heart failure was coronary heart disease, and all but one were in New York Heart Association (NYHA) class IV. Other complicating conditions were also commonly present: other vascular disease $(n=7)$, diabetes mellitus $(n=4)$, chronic obstructive pulmonary disease $(n=1)$, and renal disease $(n=4)$. All patients were severely symptomatic with marked peripheral oedema. Left ventricular ejection fraction values, by cross sectional echocardiography, were $21-30 \%$ ( $n=2$ patients), $11-20 \%(n=3)$, and less than $10 \%(n=4)$. The resting supine systolic blood pressure ranged from 130 to $60 \mathrm{~mm} \mathrm{Hg}$ (median: $90 \mathrm{~mm} \mathrm{Hg}$ ).

PREVIOUS TREATMENT

Treatment consisted of salt restriction, bed rest, and drug treatment including diuretics, ACE inhibitors, digoxin, and dopamine 
(table 1). All patients showed diuretic resistance, defined as a failure to lose weight or to develop a negative sodium balance despite bed rest, a sodium intake restriction of $80 \mathrm{mmol} / \mathrm{d}$, and high dose frusemide [1790 (SD 960) mg]. Frusemide was given orally in eight patients and by continuous intravenous infusion in four. Doses of frusemide exceeding $250 \mathrm{mg} / \mathrm{d}$ were given for at least 22 days [mean 236 (209) days] before the start of haemofiltration or haemodialysis.

\section{LABORATORY DATA AT THE START}

Before haemofiltration, renal function was considerably decreased in all patients. Endogenous creatinine clearance (ECC) ranged from 8 to $26 \mathrm{ml} / \mathrm{min} / 1.73 \mathrm{~m}^{2}$, with a mean ECC of $15.7(6.4) \mathrm{ml} / \mathrm{min} / 1.73 \mathrm{~m}^{2}$. The mean urea concentration was $40.4(13.6)$ $\mathrm{mmol} / \mathrm{l}$ (ranging from 20.3 to $68.0 \mathrm{mmol} / \mathrm{l}$ ). The serum sodium concentration varied from 118 to $146 \mathrm{mmol} / \mathrm{l}$, mean $132(7 \cdot 1) \mathrm{mmol} / \mathrm{l}$. Serum potassium before treatment varied from 3.2 to $6.1 \mathrm{mmol} / 1$, mean $4.5(1.0)$ $\mathrm{mmol} / \mathrm{l}$. The mean haemoglobin concentration was $7.8(1.1) \mathrm{mmol} / \mathrm{l}$ (range 6.0 to 9.9 $\mathrm{mmol} / \mathrm{l})$.

\section{Results}

HAEMODIALYSIS AND HAEMOFILTRATION

The initial treatment consisted of haemofiltration $(n=10)$ or haemodialysis $(n=2)$. During the first session a double lumen femoral vein catheter was used as a vascular access in seven patients, a subclavian double lumen catheter in one, a Scribner shunt in one, and a Cimino-Brescia fistula in three.

The mean number of haemodialysis or haemofiltration treatments per patient was 25 (38) (ranging from one to 113). The mean treatment interval was $5 \cdot 7(9 \cdot 1)$ days (table 2$)$. The maximum treatment interval was 33 days. The mean weight reduction during the first treatment procedure was $4.0(1.7) \mathrm{kg}$ (ranging from $1 \cdot 2$ to $6 \cdot 2 \mathrm{~kg}$ ). The total weight reduction (weight before first treatment minus weight before last treatment) was $8.4(8.5) \mathrm{kg}$ (table 2).

COMPLICATIONS, QUALITY OF LIFE, SURVIVAL Four patients reported no complaints during the treatment, one reported nausea and loss of hearing as main complaints, while three suf-

Table 2 Clinical data concerning the haemofiltration treatment

\begin{tabular}{|c|c|c|c|c|c|c|}
\hline Patient & Method & $\begin{array}{l}\text { Mean } \\
\text { treatment } \\
\text { interval (days) }\end{array}$ & $\begin{array}{l}\text { Total } \\
\text { weight } \\
\text { reduction }(\mathrm{kg})\end{array}$ & $\begin{array}{l}\text { NYHA } \\
\text { class during } \\
\text { treatment }\end{array}$ & $\begin{array}{l}\text { Period of } \\
\text { treatment } \\
\text { (days) }\end{array}$ & $\begin{array}{l}\text { Cause of } \\
\text { death }\end{array}$ \\
\hline 1 & HD & $2 \cdot 3$ & $6 \cdot 8$ & III & 223 & DT \\
\hline 2 & HF & 1.9 & $15 \cdot 1$ & III & 21 & RI \\
\hline 3 & $\mathrm{HF}$ & 33.0 & $-7 \cdot 4$ & III & 165 & $\mathrm{CS}$ \\
\hline 4 & $\mathrm{HF}$ & 3.0 & $9 \cdot 7$ & IV & 9 & DT \\
\hline 5 & $\mathrm{HF}$ & $12 \cdot 0$ & 6.9 & IV & 24 & $\mathrm{DT}$ \\
\hline 6 & $\mathrm{HF}$ & 3.0 & $18 \cdot 7$ & III & 24 & DT \\
\hline 7 & HD & 3.5 & 1.5 & II & 393 & $\overline{F A}$ \\
\hline 8 & $\mathrm{HF}$ & $2 \cdot 2$ & 1.6 & III & 20 & $\mathrm{CS}$ \\
\hline 9 & $\mathrm{HF}$ & $1 \cdot 7$ & $7 \cdot 9$ & III & 22 & FA \\
\hline 10 & $\mathrm{HF}$ & 0.0 & $1 \cdot 2$ & IV & 0 & $\mathrm{CS}$ \\
\hline 11 & $\mathrm{HF}$ & $2 \cdot 2$ & $21 \cdot 1$ & III & 76 & RI \\
\hline 12 & $\mathrm{HF}$ & 3.0 & $17 \cdot 2$ & $\mathrm{IV}$ & 24 & FA \\
\hline
\end{tabular}

CS, cardiogenic shock; FA, fatal arrhythmia; HD, haemodialysis; HF, haemofiltration $\mathrm{RI}$, respiratory insufficiency; DT, discontinuation of treatment. fered from angina pectoris unresponsive to pharmacological treatment. Four patients became confused or had a decreased level of consciousness. Seven improved from NYHA class IV to class III, while five showed no change. In four patients the treatment was discontinued after discussion with the patient or his family. Other causes of death were hypotension (three patients), respiratory insufficiency (two patients), and sudden death probably caused by a fatal arrhythmia (three patients).

Patients were admitted to hospital for 12 (9)\% of the time during treatment with high dose frusemide. During treatment with haemofiltration or haemodialysis, patients were in hospital for $80(35.4) \%$ of the time. Eight patients were in hospital continuously, two were managed as outpatients for the major part of their treatment, while two others could be discharged for a short period [14 (of 24) and 23 (of 393) days, respectively].

The median survival after the start of haemofiltration treatment was 24 days, varying from 0 to 393 days. The median survival after the last treatment was three days, varying from 0 to 23 days.

\section{Discussion}

High dose frusemide is an effective, safe, and controllable means of treating patients with severe chronic heart failure refractory to the conventional dosages of frusemide, ${ }^{12}$ but resistance even to high dose frusemide may develop. Our study shows that the use of haemofiltration and haemodialysis in patients with end stage chronic heart failure who have become unresponsive to such pharmacological treatment is of little benefit for either length or quality of life.

Peritoneal dialysis and haemofiltration may be of value in the treatment of patients with acute heart failure unresponsive to high dosages of diuretics and inotropic drugs. ${ }^{2-7}$ However, the place of these non-pharmacological approaches used on a chronic intermittent basis in the treatment of refractory chronic heart failure remains unclear, although the idea that excess of body water can be removed on a regular basis by the use of peritoneal dialysis or haemofiltration, analogous to the treatment of end stage renal failure, seems appealing.

In contrast to haemodialysis, adverse haemodynamic effects are limited in peritoneal dialysis and haemofiltration, which makes these two techniques more suitable for the treatment of refractory chronic heart failure..$^{13}$ Despite its negative haemodynamic side effects, two patients in this study had to be treated with haemodialysis because of life threatening uraemia. Renal function was seriously impaired initially in all patients, at least in part because of heart failure, and declined further during treatment with haemofiltration in the majority.

In some of the studies describing the use of haemofiltration or peritoneal dialysis in chronic heart failure, an improvement in both haemodynamics and responsiveness to diuretics after 
the first session was observed, making further treatment of this kind unnecessary. ${ }^{24710}$ This cannot be completely explained by the influence of massive oedema on the pharmacokinetics and pharmacodynamics of high dose frusemide. ${ }^{14}$ In our study only one patient could be treated at intervals of greater than 10 days over a long period.

Life was substantially prolonged in only four patients and the median survival after the start of haemofiltration was short. Moreover, most patients were in hospital throughout the period of haemodialysis. Any improvement in NYHA class was limited. The slight benefit, combined with the high cost, make it questionable whether patients with end stage chronic heart failure refractory to high dose frusemide should be offered chronic haemofiltration.

The addition of a thiazide diuretic, acting on the distal tubule, is effective, even in patients with markedly impaired renal function. ${ }^{15}$ Treatment with a combination of diuretics acting on different segments of the nephron may be an alternative to chronic intermittent haemofiltration. In our view treatment with haemofiltration or haemodialysis in patients with chronic heart failure should only be considered when a remediable cause of heart failure is suspected or as a bridge to heart transplantation. ${ }^{1012}$

1 Rodeheffer RJ, Jacobsen SJ, Gersch BJ, Phil D, Kottke TE, McCann A, et al. The incidence and prevalence of con- gestive heart failure in Rochester, Minnesota. Mayo Clin Proc 1993;68:1143-50.

2 Rimondini A, Cipolla CM, Della Bella P, Grazi S, Sisillio $\mathrm{E}$, Susini $\mathrm{G}$, et al. Hemofiltration as short-term treatment for refractory congestive heart failure. $\mathrm{Am} \mathcal{F} \mathrm{Med} 1987$; 83:43-8.

3 Silverstein ME, Ford CA, Lysaght MJ, Henderson LW. Treatment of severe fluid overload by ultrafiltration. $N$ Engl F Med 1974;291:747-51.

4 Morgan SH, Mansell MA, Thompson FD. Fluid removal by hemofiltration in diuretic resistant cardiac failure. $\mathrm{Br}$ Heart $\mathcal{F} 1985 ; 54: 218-9$.

5 Simpson IA, Rae AP, Simpson K, Gribben J, Boulton Jones JM, Allison MEM, et al. Ultrafiltration in the management of refractory congestive heart failure. $\mathrm{Br} \mathrm{Heart} \mathcal{F}$ 1986;55:344-7.

6 Shilo S, Slotki IN, Iaina A. Improved renal function following acute peritoneal dialysis in patients with intractable

congestive heart failure. Israel $\mathcal{F}$ Med Sci 1987;23:821-4.
7 Fauchald P, Forfang K, Amlie J. An evaluation of ultrafiltration as treatment of therapy-resistant cardiac edema. tration as treatment of therapy-resi

8 Biasoli S, Barbaresi M, Petrosino L, Cavallini L, Zambello A, Cavalcanti $\mathrm{G}$, et al. Intermittent venovenous hemofiltration as a chronic treatment for refractory and intractable heart failure. ASAIO f 1992;38:M658-63.

9 McKinnie JJ, Bourgeois RJ, Husserl FE. Long-term therapy for heart failure with continuous ambulatory peritoneal dialysis. Arch Intern Med 1985;145:1128-9.

10 Rubin J, Ball R. Continuous ambulatory peritoneal dialysis as treatment of severe congestive heart failure in the face of chronic renal failure. Arch Intern Med 1986;146:1533-6.

11 Konig P, Geissler D, Lechleitner P, Spielberger M, Dittrich $P$. Improved management of congestive heart failure: use of continuous ambulatory peritoneal dialysis. Arch Intern Med 1987;147:1031-4.

12 Gerlag P, van Meyel J. High dose frusemide in the treatment of refractory congestive heart failure. Arch Intern Med 1988;148:286-91.

13 Ultrafiltration and haemofiltration for refractory congestive cardiac failure [editorial]. Lancet 1986;ii:1193.

14 van Meyel J, Gerlag P, Smits P, Russel F, Tan Y, van Ginneken $\mathrm{C}$, et al. Absorbtion of high dose frusemide in congestive heart failure. Clin Pharmacokinet 1992;22: 308-18.

15 Dormans T, Gerlag P. Combination of high-dose frusemide and hydrochlorothiazide in the treatment of refractory congestive heart failure. In: Diuretics IV: chemistry, tory congestive heart failure. In: Diuretics IV: chemistry,
pharmacology and clinical applications. Amsterdam: pharmacology and clinica
Excerpta Medica, 1993. 